\title{
First description of the male of Zelotes haifaensis Levy, 2009 (Aranei: Gnaphosidae)
}

\author{
Первоописание самца Zelotes haifaensis Levy, 2009 \\ (Aranei: Gnaphosidae)
}

\section{Yuri M. Marusik ${ }^{1,2}$, Sergei L. Zonstein ${ }^{2,3}$ \& Mikhail M. Omelko ${ }^{2,4,5}$ Ю.М. Марусик, С.А. Зонштейн, М.М. Омелько $2,4,5$}

\footnotetext{
${ }^{1}$ Institute for Biological Problems of the North, Portovaya Str. 18, Magadan 685000, Russia. E-mail: yurmar@mail.ru.

${ }^{2}$ Zoological Museum, University of Turku, FI-20014 Turku, Finland.

${ }^{3}$ Department of Zoology, The George S. Wise Faculty of Life Sciences, Tel-Aviv University, 69978 Tel-Aviv, Israel. E-mail: znn@post.tau.ac.il

${ }^{4}$ Gornotaezhnaya Station FEB RAS, Gornotaezhnoe Vil., Ussuriyski Dist., Primorski krai 692533 Russia. E-mail: omelkom@gmail.com.

${ }^{5}$ Far Eastern Federal University, Sukhanova 8, Vladivostok 690950, Russia.

${ }^{1}$ Институт биологических проблем Севера ДВ РАН, Портовая 18, Магадан 685000, Россия.

${ }^{4}$ Горнотаёжная станция им. В.Л. Комарова ДВО РАН, с. Горнотаёжное, Уссурийский район, Приморский край 692533, Россия.

5 Дальневосточный Федеральный университет, Суханова 8, Владивосток 690950, Россия.
}

KEY WORDS: Aranei, Israel, ground spiders, species group, Zelotes.

КЛЮЧЕВЫЕ СЛОВА: Aranei, Израиль, пауки, группа видов, Zelotes.

ABSTRACT: The male of Zelotes haifaensis Levy, 2009, is described for the first time from topotype material. The species is restricted to the Carmel Range, northern Israel.

РЕЗЮМЕ: Впервые описан самец Zelotes haifaensis Levy, 2009 на основе материалов собранных в типовой местности. Распространение вида ограничено только хребтом Кармель, что на севере Израиля.

\section{Introduction}

Spiders of the family Gnaphosidae are rather well studied in Israel thanks to the numerous publications by Gershom Levy [1995, 1998, 1999a,b, 2002, 2004, 2009]. It is the most species-rich family in the country, with 126 species belonging to 27 genera [Zonstein \& Marusik, 2013]. The high level of knowledge of this family in Israel can be shown by the number of Gnaphosidae species in Israel $(20 \%)$ is higher than that in any other Mediterranean country [Zonstein \& Marusik, 2013]. Only France, Iberian Peninsula and Italy have more species of ground spiders $(169,168,144$, respectively). Although the family Gnaphosidae is well studied in Israel, 30 species (or $1 / 4$ of the whole fauna) are known by one sex. While studying fauna of Israel we found several samples containing males of Zelotes haifaensis Levy, 2009, a species previously known only by females. Some samples contained both females and males and all comes from nearby the type locality. Main goal of this paper is to provide a redescription of the female of $Z$. haifaensis, and the first description of the male.

\section{Material and Methods}

Photographs were taken in dishes of different sizes with paraffin at the bottom. Specimens were photographed using an Olympus Camedia E-520 camera attached to an Olympus SZX16 stereomicroscope at the Zoological Museum, University of Turku. SEM microphotographs were made with a JEOL JSM-5200 in the Zoological Museum, University of Turku. Digital images were prepared using "CombineZP" image stacking software. Epigynes were macerated in $10 \% \mathrm{KOH}$ solution and painted with methylene blue. All measurements are given in $\mathrm{mm}$.

Measurements and descriptions were made after Levy [1998]. The length of each leg is the combined length of all its segments (each segment measured separately) from femur to tarsus; the more proximal segments are excluded. The proportional indices used are: the carapace index (length divided by width), labial index (length divided by width), clypeal index (height of clypeus divided by diameter of anterior median eye), MOQ (median ocular quadrangle) index (length of carapace divided by longitudinal axis of MOQ) and patella-tibia index (combined length of both segments of the first leg divided by length of carapace).

Abbreviations of the museums: HUJ - Hebrew University of Jerusalem; MMUM the Manchester Museum, the University of Manchester; TAU — Tel Aviv University; ZMMU - Zoological Museum of the Moscow State University. 

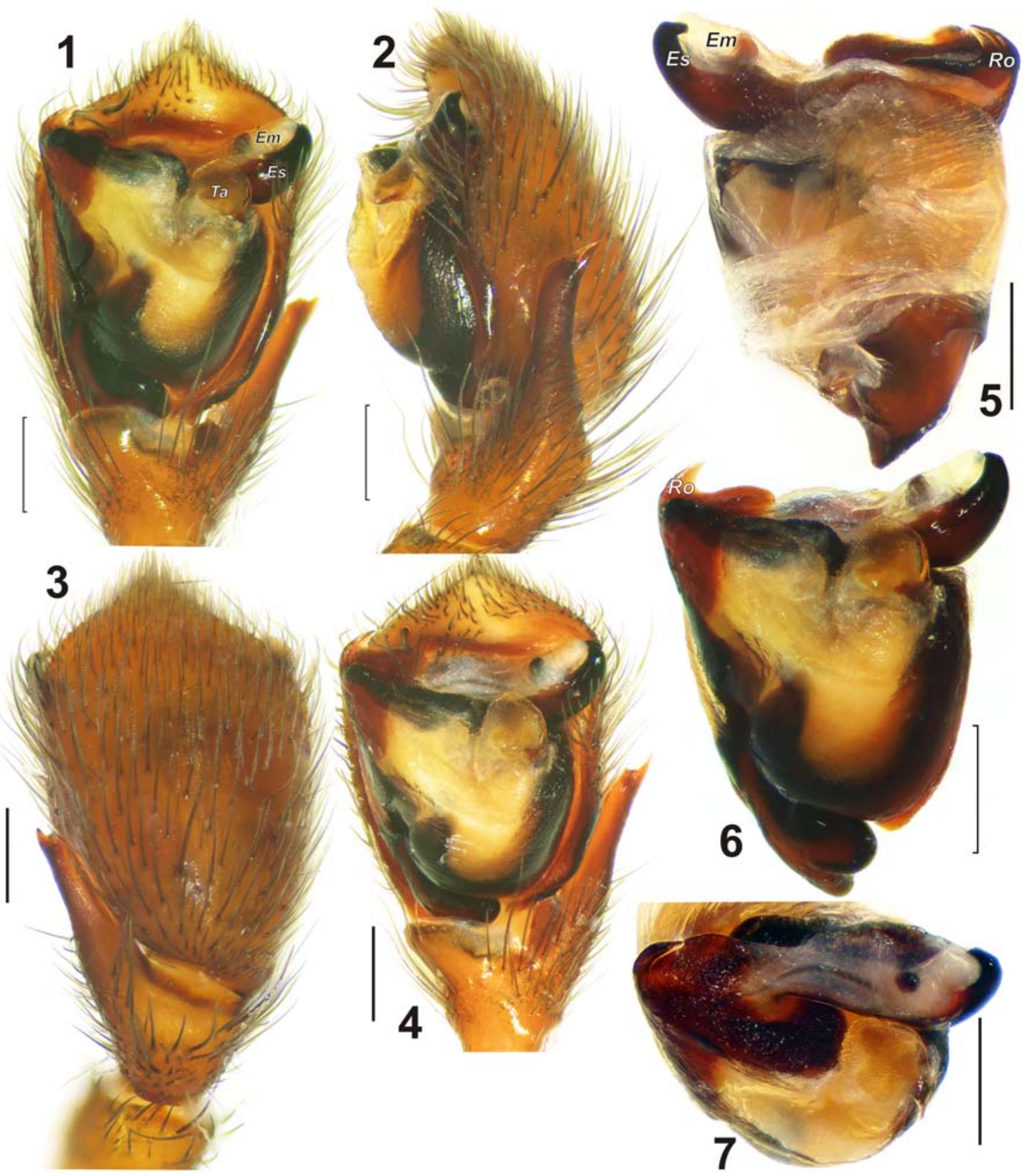

Figs 1-7. Male palp of Zelotes haifaensis: 1 - ventral; 2 - retrolateral; 3 - dorsal; 4 - ventro-apical; 5-7 - bulbus, dorsal, ventral and apical respectively. Scale $0.2 \mathrm{~mm}$. Abbreviations: $E m-$ membranous part of embolus, $E s$ - sclerotized part of embolus, Ro outgrowth of radix; $\mathrm{Ta}$ - tegular apophysis.

Рис. 1-7. Пальпа самца Zelotes haifaensis: 1 - вентрально; 2 - ретролатерально; 3 - дорзально; 5-7 - бульбус, дорзально, вентрально и сверху. Масштаб 0,2 мм. Сокращения: $E m$ - мембранизированная часть эмболюса, Es - склеротизированная часть эмболюса, $R o$ - вырост радикса; $\mathrm{Ta}$ - тегулярный отросток.

\section{Taxonomic Part}

\section{Zelotes haifaensis Levy, 2009}

Figs 1-10.

Z. meronensis Levy, 1998: 120, f. 54-55 ( + , misidentified). Z. h. Levy, 2009: 34 (官.
MATERIAL EXAMINED: ISRAEL: Holotype + (HUJ 14494), Haifa, March 1987 (V. Roth); 1 \% (MMUM) south part of Carmel Ridge, $1 \mathrm{~km} \mathrm{~N}$ of Bat Shlomo, 32 $36^{\prime} \mathrm{N} 35^{\circ} 00^{\prime} \mathrm{E}, 150 \mathrm{~m}, 12.12 .2011$ (S.L. Zonstein); $20^{7} 0^{7} 1$ ( TAU), Carmel Ridge, Bat Shlomo, $32^{\circ} 35.5^{\prime} \mathrm{N} 34^{\circ} 59.7^{\prime} \mathrm{E}, 6.03 .2013$ (S.L. Zonstein); 1 ○ $^{\top} 2$ 우

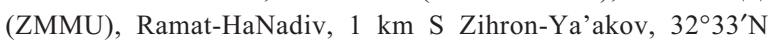
$34^{\circ} 57^{\prime} \mathrm{E}, 130 \mathrm{~m}, 15.12 .2011$ (S.L. Zonstein). 

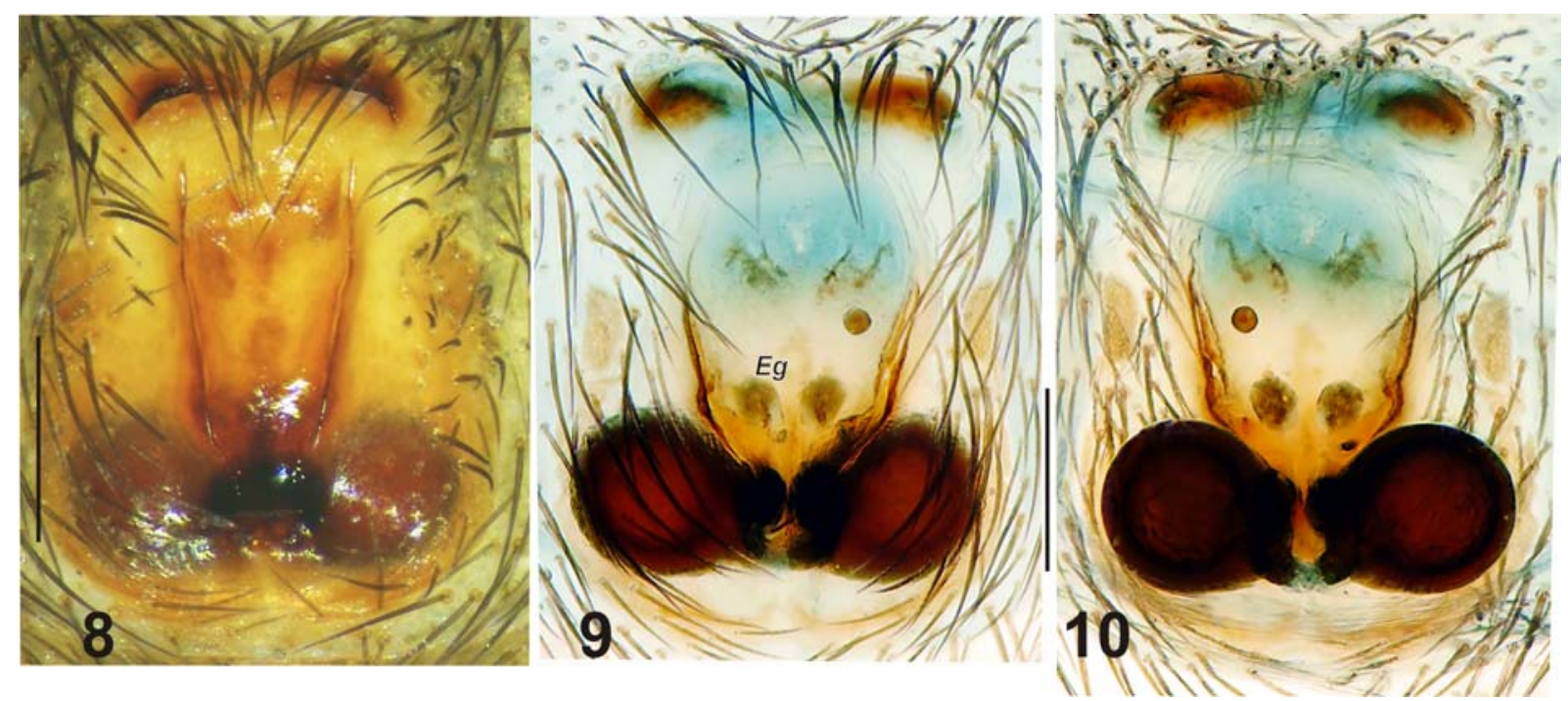

Figs 8-10. Epigyne of Zelotes haifaensis: 8-9 — ventral; 10 - dorsal. 9-10 - after maceration. Scale 0.2 mm. Abbreviation: Eg pigynal gland.

Рис. 8-10. Эпигина Zelotes haifaensis: 8-9 - вентрально; 10 - дорзально. 9-10 - мацерированная. Масштаб 0,2 мм. Сокращение: $E g$ - железа эпигины.

COMMENTS. The holotype female of this species was first mismatched, and selected as a paratype of $Z$. meronensis Levy, 1998. Later Levy [2009] recognized the mistake and described a new species on the basis of a single female.

Zelotes haifaensis belongs to the Z. argoliensis (C.L. Koch, 1839) species group which encompasses also $Z$. meronensis Levy, 1998 and Z. galunae Levy, 1998. All four species occur in Israel. This group was created by Levy [1998] who called it "galuni subgroup".

DIAGNOSIS. Zelotes haifaensis differs from its congroupers by having a relatively wide or fused apical pockets of epigyne, large receptacles, long tibial apophysis with a bent and sharply pointed tip. The embolus of this species is rather similar to those of Z. galunae. The two species can be easily separated by the shape of radical apophysis: it is strongly bent and directed almost retrolaterally in Z. haifaensis and is directed almost apically in $Z$. galunae.

DESCRIPTION. Male. Total length 5.25. Carapace 2.75 long, 2.07, length/width ratio 1.33; labial index 1.48; clypeal index 1.8; MOQ index 8.3; leg length I 6.73, II 5.88, III 5.08, IV 8.48; patella-tibia index 0.97 . Whole body and legs dark brown.

Palp as in Figs 1-7, retrolateral apophysis long (about twice as long as the tibia), sharply pointed, its tip bent dorsally; cymbium widened at the level of embolus; tip of cymbium triangular; tegular apophysis $(\mathrm{Ta})$ relatively small, almost circular in ventral view (Fig. 1); embolus long and wide (Fig. 7), its tip consists of heavily sclerotized $(E S)$ and membranous $(E m)$ parts; radix with claw like outgrowth $(R o)$.

Female (holotype, after Levy, 1998). Total length 6.8. Carapace 3.1 long, 2.3 wide, length/width ratio 1.35; labial index 1.43; clypeal index 1.83; MOQ index 10.69; leg lengths: I 16.6; II 5.8; III 5.2; IV 8.3; patella-tibia index 0.84 . Whole body and legs dark brown.

Epigyne as in Figs 8-10. Epigyne on Figs 9-10 has different proportion than in Fig. 8, because it was slightly bent after maceration. Fovea long with almost parallel margins; apical pockets variable, from fused to well separated as in Figs 9-10. Receptacles large, round, their diameters are equal to fovea width; glands $(E g)$ spaced from each other and from receptacles by their diameter.

DISTRIBUTION. The species is known exclusively the environs of Haifa in the Carmel Range on the area $30 \mathrm{~km}$ long and $20 \mathrm{~km}$ wide.

ACKNOWLEDGEMENTS. We thank Seppo Koponen (University of Turku) for providing museums facilities. English of the final draft was kindly checked by Robin Leech (Edmonton, Canada). This work was supported in part by the Russian Foundation for Basic Research (grants \#\# 11-0401716 and 12-04-01548, Far Eastern Federal University) and by the Ministry of Absorption of Israel.

\section{References}

Levy G. 1995. Revision of the spider subfamily Gnaphosinae in Israel (Araneae: Gnaphosidae) // Journal of Natural History, London. Vol.29. P.919-981.

Levy G. 1998. The ground-spider genera Setaphis, Trachyzelotes, Zelotes and Drassyllus (Araneae: Gnaphosidae) in Israel // Israel Journal of Zoology. Vol.44. P.93-158.

Levy G. 1999a. Spiders of the genera Anagraphis and Talanites (Araneae, Gnaphosidae) from Israel // Israel Journal of Zoology. Vol.45. P.215-225.

Levy G. 1999b. Spiders of six uncommon drassodine genera (Araneae: Gnaphosidae) from Israel // Israel Journal of Zoology. Vol.45. P.427-452. 
Levy G. 2002. Spiders of the genera Micaria and Aphantaulax (Araneae, Gnaphosidae) from Israel // Israel Journal of Zoology. Vol.48. P.111-134.

Levy G. 2004. Spiders of the genera Drassodes and Haplodrassus (Araneae, Gnaphosidae) from Israel // Israel Journal of Zoology. Vol.50. P.1-37.
Levy G. 2009. New ground-spider genera and species with annexed checklist of the Gnaphosidae (Araneae) of Israel // Zootaxa. Vol.2066. P.1-49.

Zonstein S.L., Marusik Yu.M. 2013. Checklist of the spiders (Araneae) of Israel // Zootaxa. Vol. 3671. No.1. P.1-127.

Responsible editor K.G. Mikhailov 